九州大学学術情報リポジトリ

Kyushu University Institutional Repository

\title{
Oxidative stress and androgen receptor signaling in the development and progression of castration-resistant prostate cancer
}

Shiota, Masaki

Departments of Molecular Biology, Kitakyushu| Department of Urology, Graduate School of Medical Sciences, Kyushu University

Yokomizo, Akira

Department of Urology, Graduate School of Medical Sciences, Kyushu University

Naito, Se ij i

Department of Urology, Graduate School of Medical Sciences, Kyushu University

http://hdl. handle. net/2324/25602

出版情報 : Free Radical Biology and Medicine. 51 (7), pp.1320-1328，2011-10-01. Elsevier バージョン:

権利関係: (C) 2011 Elsevier Inc. 
Oxidative stress and androgen receptor signaling in the development and progression of castration-resistant prostate cancer

Masaki Shiota, Akira Yokomizo and Seiji Naito

Department of Urology, Graduate School of Medical Sciences, Kyushu University, Fukuoka, Japan

Correspondence to: Masaki Shiota MD, PhD, Department of Urology, Graduate School of Medical

Sciences, Kyushu University, 3-1-1 Maidashi, Higashi-ku, Fukuoka 812-8582, Japan. Tel:

+81-92-642-5603; Fax: +81-92-642-5618; E-mail: shiota@uro.med.kyushu-u.ac.jp 


\section{Abstract}

Aberrant androgen receptor (AR) signaling plays a critical role in androgen-dependent prostate cancer $(\mathrm{PCa})$, as well as castration-resistant $\mathrm{PCa}$ (CRPC). Oxidative stress appears to contribute to the tumorigenesis and progression of $\mathrm{PCa}$, as well as the development of CRPC, via activation of AR signaling. This notion is supported by the fact that there is an aberrant or improper regulation of the redox status in these disorders. Additionally, androgen deprivation-induced oxidative stress appears to be involved in the pathogenesis of several disorders caused by androgen deprivation therapy (ADT), including osteoporosis, neurodegenerative disease and cardiovascular disease. Oxidative stress can be suppressed with antioxidants or via a reduction in reactive oxygen species production. Thus, developing new therapeutic agents that reduce oxidative stress might be useful in preventing the conversion of androgen-dependent PCa into CRPC, as well as reducing the adverse effects associated with ADT. The objective of the present review was to provide an overview regarding the relationship between oxidative stress and $\mathrm{AR}$ signaling in the context of $\mathrm{PCa}$, and especially CRPC. Additionally, we discuss the potential use of antioxidant therapies in the treatment of PCa.

Keywords: androgen receptor; castration-resistant prostate cancer; oxidative stress; prostate cancer; reactive oxygen species 


\section{Introduction}

Androgens, the male sex steroids, play a key role in the development of the male phenotype during embryogenesis, sexual maturation at puberty, and male reproductive function and behavior in adulthood. Androgens also play a role in various non-reproductive tissues including bones, muscle, brain, skin, heart, blood vessels, blood and adipose tissue. However, androgens are also implicated in various pathological disorders, including prostate cancer (PCa). Testosterone, the most abundant androgen present in blood serum, is synthesized by Leydig cells of the testes. Other androgens, including dehydroepiandrosterone, androstenediol and androstenedione, are produced by the adrenal glands and may be converted into testosterone in peripheral tissues [1,2]. Free and lipophilic testosterone then diffuses throughout the cells of its target tissues and organs, where it may be converted into its (about 10-fold) more potent metabolite, dihydrotestosterone (DHT), via $5 \alpha$-reductase (type I or II) [3]. Both testosterone and DHT exert their actions by binding to the androgen receptor (AR), a $110-\mathrm{kDa}$ member of the nuclear receptor superfamily. Prior to its activation, the AR is primarily located in the cytoplasm, and makes up a complex with heat shock proteins. Upon ligand binding, the AR undergoes conformational rearrangement, homodimerizes, and translocates into the nucleus [4]. After translocating into the nucleus, the AR binds to specific recognition sequences, known as androgen response elements, in the promoter and enhancer regions of its target genes, and modulates their gene expression. 
$\mathrm{PCa}$ is the most common type of non-cutaneous cancer and the second leading cause of male cancer-related mortality in developed countries. The AR signaling pathway is known to play a critical role in prostate carcinogenesis and PCa progression. Androgen deprivation therapy (ADT) is commonly used in the treatment of $\mathrm{PCa}$, and involves either a reduction in the production of androgens via surgical or medical castration or an interference in AR function with the use of anti-androgen agents [5]. Although ADT is initially effective in approximately $90 \%$ of $\mathrm{PCa}$ cases, most cases eventually become resistant to ADT and develop castration-resistant PCa (CRPC) [5]. In CRPC, the AR signaling pathway still plays a key role in cell proliferation despite low androgen levels being achieved with ADT [6]. Activation of the AR signaling pathway in CRPC has been attributed to a number of mechanisms, including AR hypersensitivity, de novo intraprostatic androgen production, promiscuous AR activation via adrenal androgens, non-androgenic steroids and even anti-androgens, and AR activation via growth factors and cytokines through intracellular signal-transduction pathways [7]. These phenomena may result from abnormalities in the AR (i.e. mutation and overexpression) and/or its related molecules (e.g. AR co-regulators). Furthermore, it has been recently reported that some AR splice variants may exert significant constitutive effects in the absence of ligands [8-12].

Hydroxyl radicals, peroxides and superoxides are reactive oxygen species (ROS) generated during metabolic processes. ROS generated either from endogenous or external sources play a key 
role in regulating a wide range of biological mechanisms [13]. Although increased ROS production has been traditionally associated with tissue injury or DNA damage, an increase in ROS production in several cellular processes is also associated with neoplastic transformation and aberrant cellular proliferation $[14,15]$. In addition, processes associated with proliferation, apoptosis and senescence may be due to the activation of various signaling pathways in response to intracellular changes in ROS levels [16]. Thus, excessive ROS production or impairment of antioxidant defense systems can induce oxidative stress. This increase in ROS levels may contribute to the initiation and development of various cancers, including PCa, since oxidative stress regulates cellular fate in various systems.

Oxidative stress has been shown to play a key role in prostate carcinogenesis and $\mathrm{PCa}$ progression $[17,18]$. It has been recently reported that oxidative stress is implicated in the conversion of androgen-dependent PCa into CRPC via regulation of AR expression [19]. However, the mechanisms by which oxidative stress alters AR signaling and thereby induces CRPC are not fully understood and need to be further explored. Thus, in the present review, we will summarize the currently available research on the role of oxidative stress in AR signaling and CRPC pathology, as well as several disorders caused by ADT, including osteoporosis, neurodegenerative disease and cardiovascular disease (Fig. 1). Additionally, we will discuss the potential role of antioxidant therapy in the treatment of $\mathrm{PCa}$, especially in preventing the conversion of androgen-dependent $\mathrm{PCa}$ into CRPC. 


\section{Effects of AR signaling on oxidative stress}

Several reports have suggested that blockade of AR signaling may induce oxidative stress in various systems. It has also been shown that castration induces oxidative stress in the rat prostate by significantly upregulating ROS-generating NADPH oxidases and downregulating ROS-detoxifying enzymes [20]. Additionally, it was found that ADT decreases the mRNA expression levels of a major ROS scavenger, manganese superoxide dismutase (MnSOD), in biopsy tissues of PCa [21]. Furthermore, gene expression of ROS-detoxifying enzymes induced by oxidative stress, such as thioredoxin 1, peroxiredoxin ( $\operatorname{Prx}) 5$, and MnSOD, is reduced in the rat prostate following castration [22]. In addition, it was recently reported that thioredoxin 1 was reduced and oxidative stress was increased by androgen deprivation compared with those by androgen replacement [23]. MnSOD is located in mitochondria and implicated in protecting mitochondrial DNA from damage induced via oxidative stress. Recently, mitochondrial gene mutations were shown to upregulate intracellular ROS levels and lead to the development of malignancies [24]. These results were corroborated by previous observations, where increased oxidative cellular damage accompanied by declining testosterone levels was associated with the development of malignancies [17,25] and aging [26-28]. Additionally, ROS levels in myocardial cells of AR-knockout mice were found to be higher than those of wild-type mice when the anticancer drug, doxorubicin, was administered. Doxorubicin is 
known to cause cardiotoxicity through oxidative stress and thereby result in greater doxorubicin-induced cardiotoxicity among the AR-knockout mice [29]. Also, it was found that castration of male mice evoked an increase in oxidative stress within their skeletal system [30,31].

Conversely, there are several reports suggesting that androgen may increase oxidative stress [32-34]. Ripple et al. reported there was an increase in oxidative stress, and lipid peroxidation, in androgen-dependent PCa LNCaP cells following exposure to androgens (i.e. DHT and R1881) [32]. Similarly, both Pinthus et al. and Pathak et al. reported that androgen exposure induces oxidative stress in AR-positive PCa cells [33,34]. Furthermore, it was recently reported that androgen-induced oxidative stress, achieved with $10 \mathrm{nM}$ of R1881 in 22Rv1, was due to the activation of NADPH oxidase [35]. Despite the equivocal evidence with respect to the interaction between androgen and oxidative stress, it may be that both androgen deprivation and androgen exposure induce oxidative stress via different mechanisms. For example, androgen deprivation in an androgen-positive milieu or androgen exposure in an androgen-negative milieu may both evoke various stresses in PCa cells. Thus, given that all the above-mentioned studies had added androgen to an androgen-negative milieu, their findings may not reflect the clinical situation of ADT. Nevertheless, androgen deprivation, which mimics clinical ADT, induces oxidative stress, suggesting that ADT may also induce oxidative stress in human tissues and tumors, including PCa. 


\section{Effects of oxidative stress on AR signaling}

Given that androgen deprivation induces oxidative stress in PCa cells, the effects of oxidative stress on AR signaling are reviewed in this section (Fig. 2). AR signaling is augmented in CRPC, or a low-androgen milieu, by the various mechanisms, including: (1) AR overexpression, (2) AR mutations or splice variants, (3) AR co-regulators, (4) AR activation by growth factors and cytokines through intracellular signal-transduction pathways, and (5) de novo intraprostatic androgen synthesis.

\section{(1) AR overexpression}

AR overexpression is thought to be one of the major causes of CRPC. AR overexpression can be attributed to gene amplification, transcriptional upregulation, translational upregulation and decreased degradation. Many studies have shown that the progression of CRPC is associated with increased AR expression [36-39]. AR gene overexpression occurs in most cases of CRPC, where in the majority of CRPC cases, the $A R$ gene undergoes transcriptional upregulation, and in approximately $10-20 \%$ of these cases, the $A R$ gene is amplified [40].

We previously reported that Twist 1 was upregulated by oxidative stress, and in turn, Twist1 upregulated $A R$ transcription directly by binding to the $A R$ promoter region. This observation was 
consistent with the finding that CRPC cells expressed higher levels of AR transcript and protein, as well as Twist1 protein, than androgen-dependent PCa cells [19]. Moreover, we recently reported that Y-box binding protein-1 (YB-1) was also involved in $A R$ transcription [41]. YB-1 is also a stress-related protein. YB-1 translocates into nucleus in response to various stressors, including ultraviolet radiation and the anticancer agent, paclitaxel $[42,43]$. In addition, YB-1 is a major target gene of Twist1 [44-46], and vice versa [47]. These findings suggest that both YB-1 and Twist1 may promote $A R$ transcription.

Of the transcription factors that regulate $A R$ transcription [48], several transcription factors appear to be also implicated in oxidative stress. The transcription factor, NFkB, is well known to be induced by cytokines and inflammation, as well as various stressors, including oxidative stress. c-Myc may also induced by certain stressors, such as ultraviolet radiation [49]. These transcription factors are shown to positively regulate $A R$ transcription [50-52]. Also, CREB and Sp1 have been suggested to be involved in the oxidative stress signaling pathway $[53,54]$, as well as in regulating $A R$ transcription [55-57]. Moreover, Foxo3a, which protects cells from oxidative stress, also regulates $A R$ transcription [58]. Lastly, the above-mentioned transcription factors involved in oxidative stress/AR signaling pathway via the modulation of $A R$ transcription may also involve the Twist1/YB-1 signaling pathway. These findings suggest that there is a close relationship between oxidative stress and AR expression. 


\section{(2) AR mutations or splice variants}

Mutations in the $A R$ gene may create a promiscuous receptor, and thereby alter the interactions between its co-regulating proteins and intramolecular $\mathrm{NH}_{2}-\mathrm{COOH}$ moieties [59]. Approximately 70 different missense mutations have been documented in clinical samples, with varying consequences on AR activity. These mutations and their effects on the AR have been previously reviewed in [59,60]. Mutations in the ligand-binding domain of the AR, such as H874Y, T877A, and T877S, increase the binding capacity of the AR to motifs associated with its co-regulatory proteins, stimulate the expression of AR target genes, and make it susceptible to being activated by other hormones and even anti-androgens [61]. Although oxidative stress is well known to induce DNA mutation through the oxidation of nucleotides, to the best of our knowledge, no reports exist on oxidative stress-induced mutations in the $A R$ gene.

In addition to $A R$ mutations, several $A R$ splice variants have been recently identified. Their role in promoting castration-resistant growth in PCa cells has been of much interest, since such splice variants exhibit transcriptional activity in the absence of androgen [8-12]. It is thought that AR splice variants may contribute to the promotion of CRPC, as there is no need for a ligand in its activation. However, so far, to the best of our knowledge, there are no reports on the relationship between AR splice variants and oxidative stress. 


\section{(3) AR co-regulators}

The importance of AR co-regulators in the activation of AR signaling has been previously recognized [62]. Throughout the development and progression of $\mathrm{PCa}$, a subset of AR co-activators have been shown to be overexpressed or over activated. Additionally, the deregulation of AR co-activators tends to increase with tumor progression, correlate with the aggressiveness and poor prognosis of PCa, and contribute to the development of CRPC $[62,63]$.

Previously, Prx1 was reported to be one of the co-activators involved in facilitating the binding of androgen to the AR $[64,65]$. The Prx family consists of six members (i.e. typical 2-Cys, Prx1-4; atypical 2-Cys, Prx5; and 1-Cys, Prx6), and plays a critical role in the redox-dependent signal transduction pathway, as well as protecting cells from cytotoxicity induced via oxidative stress [66]. Generally, Prxs are thought to be upregulated by oxidative stress. Specifically, Prx1 is regulated by a transcription factor induced by oxidative stress, known as NF-E2-related factor 2 (Nrf2) [67]. Additionally, we have found that Ets, a transcription factor also induced by oxidative stress, is upregulated by high-mobility group protein $\mathrm{B} 1$, a protein implicated in the oxidative stress-induced regulation of Prx 1 and Prx5 expression [68]. These findings suggest that Prx1 expression is regulated by oxidative stress. Recent findings also suggest that Prx 2 expression is regulated by oxidative stress through the Foxo3a transcription factor [69], which has been implicated in $A R$ 
transcription and cellular responses to oxidative stress $[58,70]$. We found that of all the members of the Prx family, Prx2 was the most overexpressed in CRPC and hydrogen peroxide-resistant cells. Prx2 was also found to augment AR transactivation by acting as an AR co-activator. Moreover, it was found that cytoplasmic Prx2 enhances AR transactivation, while nuclear Prx2 decreases it, suggesting that the redox status of the nucleus and cytoplasm might affect AR signaling through Prx2 [71]. Similarly, it was reported that the oxidized forms of nuclear thioredoxin 1 were higher in prostate cancer cell lines compared with benign prostate epithelial cells, suggesting that nuclear redox imbalance occurred [23]. These notions are supported by the report that AR binding to DNA was inhibited by oxidizing reagent prior to AR DNA binding in vitro whereas AR dissociation with DNA was also mitigated by oxidizing reagent after AR DNA binding, these phenomena likely result from cross-linking of cysteine residues in the DNA-binding domain of AR [72].

There are other AR co-regulators are implicated in oxidative stress. Hsp27 is a cytoprotective chaperone that is induced in response to various stressors, including oxidative stress. Hsp27 regulates AR transactivation by increasing AR stability [73]. Additionally, signal transducers and activators of transcription (STAT) 3, a downstream protein in the Janus-activated protein kinase (JAK)/STAT pathway, is activated by oxidative stress, and is a well-known AR co-activator [74-76]. Early growth response-1 (Egr-1) is another AR co-activator [77], which is induced by injury, mitogens, and cytokines, as well as various stressors [78]. Thus, oxidative stress regulates AR 
signaling by regulating the expression levels of various AR co-regulators, and thereby inducing transcription of AR target genes.

(4) AR activation by growth factors and cytokines through intracellular signal-transduction pathways

Androgen-induced prostate epithelial and PCa cell proliferation is regulated by an indirect pathway involving paracrine mediators produced by stromal cells, such as insulin-like growth factor, fibroblast growth factor, and epidermal growth factor $[79,80]$. These growth factors and cytokines interact with AR signaling through their downstream intracellular signal transduction pathways.

AR signaling is influenced by a complex web of signal cascades, such as mitogen-activated protein kinase (MAPK), JAK/STAT, phosphatidylinositol-3-kinase (PI3K)/Akt, protein kinase C (PKC) and protein kinase A (PKA) [81-86]. The most significant effects of oxidative stress have been observed in pathways involving MAPK $[87,88]$. Activation of the extracellular-regulated kinase [87,88], c-Jun N-terminal kinase [89], and p38 [90] subfamilies of the MAPK pathways occur in response to changes in the cellular redox balance [91]. In addition, the JAK/STAT and PKC pathways are activated by oxidative stress [92,93]. Both the PKA [53] and PI3K/Akt [94] pathways may also be involved in mechanisms that target oxidative stress. Taken together, these findings suggest that oxidative stress affects AR signaling via various intracellular signal-transduction 
pathways.

\section{(5) De novo intraprostatic androgen synthesis}

Another mechanism by which AR signaling may be augmented in CRPC is via intratumoral repletion of endogenous AR agonists. This was first suggested in studies assessing the prostate tissues of patients that had demonstrated the progression of tumors following castration and DHT concentrations similar to untreated tumors [95]. Other studies found that while DHT levels may be somewhat depleted in CRPC tumors, intratumoral testosterone concentrations are similar to those of untreated PCa [96,97]. Recently, intratumoral conversion of adrenal androgens and de novo steroid synthesis have been brought forward as potential causes of tumor progression [97-99]. The presence of active AR in CRPC samples and high intratumoral testosterone and DHT concentrations among CRPC patients with castrate levels of serum androgen support the concept of intratumoral conversion of steroidal precursors [97,100]. Recent publications have re-emphasized that intratumoral de novo steroidogenesis can occur by demonstrating that expression of steroidogenic enzymes occurs in both normal prostate and PCa tissue $[97,99,101,102]$, and that there is a differential expression pattern between the various tumor types and the normal prostate gland [97,99]. Furthermore, a radio-labeled steroid precursor, acetic acid, was shown to be converted into DHT in androgen-dependent PCa and CRPC cells [98]. The potential upregulation of steroidogenic 
enzymes in CRPC and the resulting production of local testosterone and DHT may explain the observed increase in intratumoral androgen levels, which are sufficient to activate the AR $[97,98,100,103]$. However, to the best of our knowledge, there are no reports to date on the relationship between androgen synthesis and oxidative stress. Future research on the interaction between androgen synthesis and oxidative stress is thus warranted.

\section{Oxidative stress and the progression of castration-resistant PCa}

It is well known that MnSOD expression is markedly decreased in CRPC. MnSOD converts superoxides into less reactive species, and thereby decreases oxidative stress. Conversely, a decrease in MnSOD expression causes an increase in oxidative stress. Recently, it was reported that there was an increase in AR activity in PCa following inhibition of MnSOD expression. Specifically, a knockdown in MnSOD expression induced a similar change in androgen gene expression, and augmented the DNA-binding ability and transactivation of the AR, which was reversed by $N$-acetyl-cysteine (NAC) [104].

We also found that there is a close relationship between oxidative stress and castration resistance in PCa. Hydrogen peroxide-resistant LNCaP derivatives of androgen-dependent PCa cells exhibit a castration-resistant phenotype [19]. As described in the section above, oxidative stress can 
activate AR signaling via the interaction with various pathways. Since dysregulated AR signaling leads to castration-resistant growth in $\mathrm{PCa}$, oxidative stress also induces castration resistance through the activation of AR signaling.

\section{Interactions between oxidative stress and AR signaling in other conditions}

ADT is known to lead to numerous adverse effects, such as osteoporosis, obesity, cognitive disorders, lipid alterations, insulin resistance, and increased risk for diabetes and cardiovascular morbidity [105-107]. The pathogenesis of these disorders is closely associated with oxidative stress. As described previously, oxidative stress can affect AR signaling in PCa. Since oxidative stress also plays a critical role in other conditions, oxidative stress induced via ADT may be implicated in the various adverse effects caused by ADT.

\section{(1) Interaction between oxidative stress and AR signaling in osteoporosis}

Osteoporosis and bone fractures accompany ADT. Osteoporosis is a skeletal disorder that involves the micro-architectural deterioration of bone tissue, which results in bone fractures [108,109]. Age, lifestyle, genetics, endocrine disorders, and oxidative stress collectively influence and contribute to the development of osteoporosis [110]. A number of studies have suggested that 
oxidative stress can exacerbate age-related bone loss [111,112]. Bone-resorbing osteoclasts generate high levels of superoxide anions and hydrogen peroxide [113]. These free radicals modulate intraand inter-cellular signaling responsible for bone loss [113]. Castrated rats are more likely to develop osteoporosis, and this can be prevented with antioxidants, such as orange and grapefruit pulps [114,115]. Similarly, citrus bioactive compounds have been shown to decrease oxidative stress and improve bone quality in castrated rats [116]. These findings suggest that antioxidants can be used to ameliorate osteoporosis induced by ADT.

The anti-apoptotic effects of sex steroids on osteocytes have been well documented in mice, rats, and humans [117-119], and may contribute to their anti-fracture properties independent of their effects on bone mineral density [120]. Almeida et al. reported that gonadectomy of mice induced a phosphorylation of $\mathrm{p} 53$ and $\mathrm{p} 66^{\text {shc }}$ in their bones, which were activated by oxidative stress and reversed by androgen or estrogen [30]. Thus, these findings suggest that androgen and estrogen deficiency induces oxidative stress in osteoclasts, thereby leading to increased bone resorption and osteoporosis. Furthermore, it was found that castration of male mice induced an increase of oxidative stress with their bones $[30,31]$.

\section{(2) Interaction between oxidative stress and AR signaling in neurodegenerative diseases}

Recently, adverse effects of ADT on cognitive function have also been recognized [106]. It 
has been demonstrated that testosterone and related androgens can attenuate neuronal loss caused by certain insults [121-123]. Additionally, Lewis et al. found that castration reduces the density of pyramidal cells in male rat spines [124]. Furthermore, previous studies have demonstrated that patients with neurodegenerative diseases display lower levels of androgens [125-130]. Taken together, these findings suggest that androgens play an important role in neuron protection. Huntington's disease, an autosomal dominant inherited neurodegenerative disease, is characterized by progressive motor and cognitive deterioration $[131,132]$. Oxidative damage is thought to play an important role in the striatal cell loss observed in Huntington's disease [133]. A study by Túnez et al. has demonstrated the neuron protective effect of sex steroid hormones (i.e. 17ß-estradiol) against cellular injury and oxidative damage induced on the striatum of ovariectomized rats [134]. This protective action was characterized by a reduction of oxidative stress and biomarkers of cellular damage. Similarly, they reported that castration triggered oxidative damage and cellular death, which were blocked by testosterone administration [135].

\section{(3) Interaction between oxidative stress and AR signaling in blood coagulation}

Cardiovascular complications are major side effects of ADT [107]. Platelets are intimately involved in the pathogenesis of thromboembolic disorders, especially in arterial forms of thrombosis. Defective regulation of platelet activation/aggregation is a predominant cause for arterial thrombosis. 
Thromboxane-dependent platelet activation is associated with cardiovascular risk factors, such as cigarette smoking $[136,137]$ and diabetes mellitus [138], and may contribute to the increased risk of myocardial infarction and stroke, as suggested by the aspirin trials [139]. These risk factors are also associated with low-grade inflammation [140] and enhanced oxidative stress [141]. Oxidative stress impairs endothelial function and promotes platelet activation and aggregation, which may play an important role in the pathogenesis of acute cardiovascular diseases.

Within the hematopoietic system, testosterone regulates fibrinogen, plasminogen activator inhibitor-1 and platelet aggregability. Previous findings indicated that testosterone downregulated fibrinogen and plasminogen activator inhibitor-1 [142]. Li et al. demonstrated that androgen inhibited experimental arterial thrombosis at physiological doses, and that its receptor was mediated via the modulation of platelet activation [143]. It was demonstrated that an addition of DHT inhibits platelet aggregation induced by hydrogen peroxide. Moreover, platelet aggregation induced by hydrogen peroxide was found to be increased in castrated rats, which was reversed by androgen replacement. These findings suggest that physiological doses of androgen and its receptor may play an important role in regulating platelet aggregation, in particular in counteracting oxidative injury [144].

(4) Interaction between oxidative stress and AR signaling in the heart 
Substantial evidence suggests that oxidative stress may play a crucial role in the pathogenesis

of cardiovascular disease $[145,146]$, such as ischemic heart disease, hypertension, atherosclerosis, hypertrophy, cardiomyopathies, and congestive heart failure. ROS are capable of not only inducing oxidative damage to various cellular components and impairing cellular energetics, but also of modulating redox signaling, and thereby inducing highly specific acute or chronic changes to the cellular environment [147]. Conversely, sex differences in cardiovascular responses to a variety of experimental interventions and the presence of specific receptors for androgens and estrogens in the myocardium of rats suggest that sex hormones play a physiological role in cardiac function [148]. Kłapcińska et al. found that castration significantly worsened the antioxidant status of the left ventricle, as evidenced by a significant decline in the activities of antioxidant enzymes (i.e. superoxide dismutase, glutathione peroxidase, catalase, and glutathione reductase), and by the increase in lipid peroxidation and nitrotyrosine concentrations [149]. These results are further supported by the fact that ADT may increase the risk of death from cardiovascular disease [150].

\section{Clinical implications of antioxidant therapy in PCa}

Given the accumulating evidence suggesting that ADT induces oxidative stress in $\mathrm{PCa}$, we speculate that antioxidant therapy may play a role in the treatment of $\mathrm{PCa}$ in patients receiving ADT.

NAC is an electrophile supporting the production of glutathione, a major intracellular 
antioxidant and functions as an antioxidant. NAC has been shown to inhibit the mitogenic activity of v-H-Ras in NIH3T3 [151], and prevent chronic ulcerative colitis-associated colorectal adenocarcinoma in mice [152]. Additionally, NAC has been shown to induce p53-dependent apoptosis in transformed mouse embryo fibroblasts (MEF), but not in normal MEF [153]. Furthermore, NAC promotes angiostatin production and vascular collapse in a breast cancer orthotopic model [154]. NAC was also shown to have a chemo-preventive effect on cancer progression due to its protective effects against UV-induced cellular damage $[155,156]$ and angiogenesis $[157,158]$. Several investigators have shown that NAC prevents the induction and maintenance of DNA damage and progression of cancer in smokers [159]. In fact, NAC has reduced staining against 8-hydroxy-2'-deoxyguanosine (8-OHdG), nitrotyrosine and 4-HNE in the prostate of TRAMP mice [160]. Therefore, taken together, antioxidant therapy with NAC appears to be promising for the treatment of PCa. In a large randomized intervention trial, EUROSCAN, it was found that both vitamin A and NAC (i.e. $600 \mathrm{mg}$ daily for 2 years) did not have any benefit in preventing tumour recurrence or the occurrence of second primary tumours in patients with head and neck or lung cancer [161]. Despite these findings, the effects of NAC may be dependent on the cancer type and route of administration.

Previously, it was found that lycopene, a carotenoid with antioxidant properties and a role in preventing oxidative damage to cellular protein, lipid and DNA, augmented the therapeutic effects of 
orchiectomy on advanced PCa [162]. Additionally, serum prostate-specific antigen levels and disease-associated symptoms in a CRPC patient were reported to be alleviated by intake of saw palmetto supplements with lycopene [163]. Although the number of enrolled patients in these clinical studies was relatively small, their findings may also suggest the potential use of lycopene combined with castration in the treatment of PCa. Similarly, vitamin E, or $\alpha$-tocopherol, also an antioxidant, has been implicated in decreasing risk of PCa mortality, suggesting that it may also be used as a therapeutic agent for preventing the progression of PCa [164]. Also, NADPH oxidase inhibitor diphenyleneiodonium chloride which functions as antioxidant by inhibiting ROS production by NADPH oxidases suppressed prostate cancer cell viability including LNCaP cells [165]. In addition, another NADPH oxidase inhibitor apocynin suppressed prostate cancer cell invasion [166].

Additionally, antioxidants may play a favorable role in reducing the adverse effects induced by ADT. As previously mentioned, ADT may cause several adverse effects, including osteoporosis, neurodegenerative disease and cardiovascular disease. Several preclinical studies have suggested that the unfavorable effects of ADT are ameliorated by antioxidants, which act to suppress oxidative stress. Therefore, antioxidant therapy with ADT may not only augment the therapeutic effects of ADT, but also suppress the adverse effects associated with ADT. 


\section{Conclusions and future directions}

Oxidative stress appears to contribute to the tumorigenesis and progression of $\mathrm{PCa}$, as well as the development of CRPC through the activation of the AR signaling pathway. This notion is supported by the fact that there is an aberrant or improper regulation of the redox status implicated in these disorders. Given that oxidative stress can be suppressed by antioxidants or via a reduction in ROS production, developing new therapeutic agents that ameliorate oxidative stress may prevent the progressive conversion of androgen-dependent PCa into CRPC, as well as reduce the adverse effects associated with $\mathrm{ADT}$ (i.e. osteoporosis, neurodegenerative disease and cardiovascular disease). However, little is known regarding the relationship between oxidative stress and AR signaling, the progression of PCa into CRPC, and the use of antioxidants with ADT in PCa. Thus, future research in the above-mentioned areas is warranted to shed some light in this field. 


\section{Acknowledgments}

We apologize in advance to the authors whose researches were inadvertently missed or could not be included because of space constraints. This work was supported, in part, by the Health Sciences Research Grant for Clinical Research for Evidence-Based Medicine and Grants-in-Aid for Cancer Research (016) from the Ministry of Health, Labour and Welfare of Japan; the Kakenhi Grants (22591769) from the Ministry of Education, Culture, Sports, Science, and Technology of Japan (MEXT); and a Grant-in-Aid for Cancer Research from the Fukuoka Foundation for Sound Health. 


\section{References}

[1] Davison, S. L.; Bell, R. Androgen physiology. Semin. Reprod. Med. 24:71-77; 2006.

[2] Rainey, W. E.; Carr, B. R.; Sasano, H.; Suzuki, T.; Mason, J. I. Dissecting human adrenal androgen production. Trends Endocrinol. Metab. 13:234-239; 2002.

[3] Russell, D. W.; Wilson, J. D. Steroid 5a-reductase: two genes/two enzymes. Annu. Rev. Biochem. 63:25-61; 1994.

[4] Prescott, J.; Coetzee, G. A. Molecular chaperones throughout the life cycle of the androgen receptor. Cancer Lett. 231:12-19; 2006.

[5] Miyamoto, H.; Messing, E. M.; Chang, C. Androgen deprivation therapy for prostate cancer: current status and future prospects. Prostate 61:332-353; 2004.

[6] Litvinov, I. V.; De Marzo, A. M.; Isaacs, J. T. Is the Achilles' heel for prostate cancer therapy a gain of function in androgen receptor signaling? J. Clin. Endocrinol. Metab. 88:2972-2982; 2003.

[7] Debes, J. D.; Tindall, D. J. Mechanisms of androgen-refractory prostate cancer. N. Engl. J. Med. 351:1488-1490; 2004.

[8] Dehm, S. M.; Schmidt, L. J.; Heemers, H. V.; Vessella, R. L.; Tindall, D. J. Splicing of a novel androgen receptor exon generates a constitutively active androgen receptor that mediates prostate cancer therapy resistance. Cancer Res. 68:5469-5477; 2008. 
[9] Hu, R.; Dunn, T. A.; Wei, S.; Isharwal, S.; Veltri, R. W.; Humphreys, E.; Han, M.; Partin, A. W.; Vessella, R. L.; Isaacs, W. B.; Bova, G. S.; Luo, J. Ligand-independent androgen receptor variants derived from splicing of cryptic exons signify hormone-refractory prostate cancer.

Cancer Res. 69:16-22; 2009.

[10] Guo, Z.; Yang, X.; Sun, F.; Jiang, R.; Linn, D. E.; Chen, H.; Chen, H.; Kong, X.; Melamed, J.; Tepper, C. G.; Kung, H. J.; Brodie, A. M.; Edwards, J.; Qiu, Y. A novel androgen receptor splice variant is up-regulated during prostate cancer progression and promotes androgen depletion-resistant growth. Cancer Res. 69:2305-2313; 2009.

[11] Sun, S.; Sprenger, C. C.; Vessella, R. L.; Haugk, K.; Soriano, K.; Mostaghel, E. A.; Page, S. T.; Coleman, I. M.; Nguyen, H. M.; Sun, H.; Nelson, P. S.; Plymate, S. R. Castration resistance in human prostate cancer is conferred by a frequently occurring androgen receptor splice variant. J. Clin. Invest. 120:2715-2730; 2010.

[12] Watson, P. A.; Chen, Y. F.; Balbas, M. D.; Wongvipat, J.; Socci, N. D.; Viale, A.; Kim, K.; Sawyers, C. L. Constitutively active androgen receptor splice variants expressed in castration-resistant prostate cancer require full-length androgen receptor. Proc. Natl. Acad. Sci. USA 107:16759-16765; 2010.

[13] Barzilai, A.; Rotman, G.; Shiloh, Y. ATM deficiency and oxidative stress: a new dimension of defective response to DNA damage. DNA Repair 1:3-25; 2002. 
[14] Naka, K.; Muraguchi, T.; Hoshii, T.; Hirao, A. Regulation of reactive oxygen species and genomic stability in hematopoietic stem cells. Antioxid. Redox Signal. 10:1883-1894; 2008.

[15] Lambeth, J. D.; Kawahara, T.: Diebold, B. Regulation of Nox and Duox enzymatic activity and expression. Free Radic. Biol. Med. 43:319-331; 2007.

[16] Sauer, H.; Wartenberg, M.; Hescheler, J. Reactive oxygen species as intracellular messengers during cell growth and differentiation. Cell. Physiol. Biochem. 11:173-186; 2001.

[17] Bostwick, D. G.; Alexander, E. E.; Singh, R.; Shan, A.; Qian, J.; Santella, R. M.; Oberley, L. W.; Yan, T.; Zhong, W.; Jiang, X.; Oberley, T. D. Antioxidant enzyme expression and reactive oxygen species damage in prostatic intraepithelial neoplasia and cancer. Cancer 89:123-134; 2000.

[18] Khandrika, L.; Kumar, B.; Koul, S.; Maroni, P.; Koul, H. K. Oxidative stress in prostate cancer. Cancer Lett. 282:125-136; 2009.

[19] Shiota, M.; Yokomizo, A.; Tada, Y.; Inokuchi, J.; Kashiwagi, E.; Masubuchi, D.; Eto, M.; Uchiumi, T.; Naito, S. Castration resistance of prostate cancer cells caused by castration-induced oxidative stress through Twist1 and androgen receptor overexpression. Oncogene 29:237-250; 2010.

[20] Tam, N. N.; Gao, Y.; Leung, Y. K.; Ho, S. M. Androgenic regulation of oxidative stress in the rat prostate: involvement of $\mathrm{NAD}(\mathrm{P}) \mathrm{H}$ oxidases and antioxidant defense machinery during 
prostatic involution and regrowth. Am. J. Pathol. 163:2513-2522; 2003.

[21] Best, C. J.; Gillespie, J. W.; Yi, Y.; Chandramouli, G. V.; Perlmutter, M. A.; Gathright, Y.; Erickson, H. S.; Georgevich, L.; Tangrea, M. A.; Duray, P. H.; González, S.; Velasco, A.; Linehan, W. M.; Matusik, R. J.; Price, D. K.; Figg, W. D.; Emmert-Buck, M. R.; Chuaqui, R. F. Molecular alterations in primary prostate cancer after androgen ablation therapy. Clin. Cancer Res. 11:6823-6834; 2005.

[22] Pang, S. T.; Dillner, K.; Wu, X.; Pousette, A.; Norstedt, G.; Flores-Morales, A. Gene expression profiling of androgen deficiency predicts a pathway of prostate apoptosis that involves genes related to oxidative stress. Endocrinology 143:4897-4906; 2002.

[23] Shan, W.; Zhong, W.; Zhao, R.; Oberley, T. D. Thioredoxin 1 as a subcellular biomarker of redox imbalance in human prostate cancer progression. Free Radic. Biol. Med. 49:2078-2087; 2010.

[24] Ishikawa, K.; Takenaga, K.; Akimoto, M.; Koshikawa, N.; Yamaguchi, A.; Imanishi, H.; Nakada, K.; Honma, Y.; Hayashi, J. ROS-generating mitochondrial DNA mutations can regulate tumor cell metastasis. Science 320:661-664; 2008.

[25] Oberley, T. D.; Zhong, W.; Szweda, L. I.; Oberley, L. W. Localization of antioxidant enzymes and oxidative damage products in normal and malignant prostate epithelium. Prostate 44:144-155; 2000 . 
[26] Ghatak, S.; Ho, S. M. Age-related changes in the activities of antioxidant enzymes and lipid peroxidation status in ventral and dorsolateral prostate lobes of noble rats. Biochem. Biophys. Res. Commun. 222:362-367; 1996.

[27] Lu, T.; Finkel, T. Free radicals and senescence. Exp. Cell. Res. 314:1918-1922; 2008.

[28] Maynard, S.; Schurman, S. H.; Harboe, C.; de Souza-Pinto, N. C.; Bohr, V. A. Base excision repair of oxidative DNA damage and association with cancer and aging. Carcinogenesis 30:2-10; 2009.

[29] Ikeda, Y.; Aihara, K.; Akaike, M.; Sato, T.; Ishikawa, K.; Ise, T.; Yagi, S.; Iwase, T.; Ueda, Y.; Yoshida, S.; Azuma, H.; Walsh, K.; Tamaki, T.; Kato, S.; Matsumoto, T. Androgen receptor counteracts Doxorubicin-induced cardiotoxicity in male mice. Mol. Endocrinol. 24:1338-1348; 2010.

[30] Almeida, M.; Han, L.; Martin-Millan, M.; Plotkin, L. I.; Stewart, S. A.; Roberson, P. K.; Kousteni, S.; O'Brien, C. A.; Bellido, T.; Parfitt, A. M.; Weinstein, R. S.; Jilka, R. L.; Manolagas, S. C. Skeletal involution by age-associated oxidative stress and its acceleration by loss of sex steroids. J. Biol. Chem. 282:27285-27297; 2007.

[31] Lean, J. M.; Davies, J. T.; Fuller, K.; Jagger, C. J.; Kirstein, B.; Partington, G. A.; Urry, Z. L.; Chambers, T. J. A crucial role for thiol antioxidants in estrogen-deficiency bone loss. J. Clin. Invest. 112:915-923; 2003. 
[32] Ripple, M. O.; Henry, W. F.; Rago, R. P.; Wilding, G. Prooxidant-antioxidant shift induced by androgen treatment of human prostate carcinoma cells. J. Natl. Cancer Inst. 89:40-48; 1997.

[33] Pinthus, J. H.; Bryskin, I.; Trachtenberg, J.; Lu, J. P.; Singh, G.; Fridman, E.; Wilson, B. C. Androgen induces adaptation to oxidative stress in prostate cancer: implications for treatment with radiation therapy. Neoplasia 9:68-80; 2007.

[34] Pathak, S.; Singh, R.; Verschoyle, R. D.; Greaves, P.; Farmer, P. B.; Steward, W. P.; Mellon, J. K.; Gescher, A. J.; Sharma, R. A. Androgen manipulation alters oxidative DNA adduct levels in androgen-sensitive prostate cancer cells grown in vitro and in vivo. Cancer Lett. 261:74-83; 2008.

[35] Lu, J. P.; Monardo, L.; Bryskin, I.; Hou, Z. F.; Trachtenberg, J.; Wilson, B. C.; Pinthus, J. H. Androgens induce oxidative stress and radiation resistance in prostate cancer cells though NADPH oxidase. Prostate Cancer Prostatic Dis. 13:39-46; 2010.

[36] Gregory, C. W.; Hamil, K. G.; Kim, D.; Hall, S. H.; Pretlow, T. G.; Mohler, J. L.; French, F. S. Androgen receptor expression in androgen-independent prostate cancer is associated with increased expression of androgen-regulated genes. Cancer Res. 58:5718-5724; 1998.

[37] Zegarra-Moro, O. L.; Schmidt, L. J.; Huang, H.; Tindall, D. J. Disruption of androgen receptor function inhibits proliferation of androgen-refractory prostate cancer cells. Cancer Res. 62:1008-1013; 2002. 
[38] Chen, C. D.; Welsbie, D. S.; Tran, C.; Baek, S. H.; Chen, R.; Vessella, R.; Rosenfeld, M. G.; Sawyers, C. L. Molecular determinants of resistance to antiandrogen therapy. Nat. Med. 10:33-39; 2004.

[39] Scher, H. I.; Sawyers, C. L. Biology of progressive, castration-resistant prostate cancer: directed therapies targeting the androgen-receptor signaling axis. J. Clin. Oncol. 23:8253-8261; 2005.

[40] Linja, M. J.; Savinainen, K. J.; Saramäki, O. R.; Tammela, T. L.; Vessella, R. L.; Visakorpi, T. Amplification and overexpression of androgen receptor gene in hormone-refractory prostate cancer. Cancer Res. 61:3550-3555; 2001.

[41] Shiota, M.; Takeuchi, A.; Song, Y.; Yokomizo, A.; Kashiwagi, E.; Uchiumi, T.; Kuroiwa, K.; Tatsugami, K.; Fujimoto, N.; Oda, Y.; Naito, S. Y-box binding protein-1 promotes androgen-independent prostate cancer cell growth through androgen receptor expression. Endocr. Relat. Cancer doi: 10.1530/ERC-11-0017.

[42] Koike, K.; Uchiumi, T.; Ohga, T.; Toh, S.; Wada, M.; Kohno, K.; Kuwano, M. Nuclear translocation of the Y-box binding protein by ultraviolet irradiation. FEBS Lett. 417:390-394; 1997.

[43] Fujita, T.; Ito, K.; Izumi, H.; Kimura, M.; Sano, M.; Nakagomi, H.; Maeno, K.; Hama, Y.; Shingu, K.; Tsuchiya, S.; Kohno, K.; Fujimori, M. Increased nuclear localization of 
transcription factor Y-box binding protein 1 accompanied by up-regulation of P-glycoprotein in breast cancer pretreated with paclitaxel. Clin. Cancer Res. 11:8837-8844; 2005.

[44] Shiota, M.; Izumi, H.; Onitsuka, T.; Miyamoto, N.; Kashiwagi, E.; Kidani, A.; Yokomizo, A.; Naito, S.; Kohno, K. Twist promotes tumor cell growth through YB-1 expression. Cancer Res. 68:98-105; 2008.

[45] Shiota, M.; Izumi, H.; Onitsuka, T.; Miyamoto, N.; Kashiwagi, E.; Kidani, A.; Hirano, G.; Takahashi, M.; Naito, S.; Kohno, K. Twist and p53 reciprocally regulate target genes via direct interaction. Oncogene 27:5543-5553; 2008.

[46] Shiota, M.; Izumi, H.; Tanimoto, A.; Takahashi, M.; Miyamoto, N.; Kashiwagi, E.; Kidani, A.; Hirano, G.; Masubuchi, D.; Fukunaka, Y.; Yasuniwa, Y.; Naito, S.; Nishizawa, S.; Sasaguri, Y.; Kohno, K. Programmed cell death protein 4 down-regulates Y-box binding protein-1 expression via a direct interaction with Twist1 to suppress cancer cell growth. Cancer Res. 69:3148-3156; 2009.

[47] Evdokimova, V.; Tognon, C.; Ng, T.; Ruzanov, P.; Melnyk, N.; Fink, D.; Sorokin, A.; Ovchinnikov, L. P.; Davicioni, E.; Triche, T. J.; Sorensen, P. H. Translational activation of snaill and other developmentally regulated transcription factors by YB-1 promotes an epithelial-mesenchymal transition. Cancer Cell 15:402-415; 2009.

[48] Shiota, M.; Yokomizo, A.; Naito, S. Increased androgen receptor transcription: a cause of 
castration-resistant prostate cancer and a possible therapeutic target. J. Mol. Endocrinol. doi: 10.1530/JME-11-0018.

[49] Alarcon-Vargas, D.; Tansey, W. P.; Ronai, Z. Regulation of c-myc stability by selective stress conditions and by MEKK1 requires aa 127-189 of c-myc. Oncogene 21:4384-4391; 2002.

[50] Grad, J. M.; Dai, J. L.; Wu, S.; Burnstein, K. L. Multiple androgen response elements and a Myc consensus site in the androgen receptor (AR) coding region are involved in androgen-mediated up-regulation of AR messenger RNA. Mol. Endocrinol. 13:1896-1911; 1999.

[51] Lee, J. G.; Zheng, R.; McCafferty-Cepero, J. M.; Burnstein, K. L.; Nanus, D. M.; Shen, R. Endothelin-1 enhances the expression of the androgen receptor via activation of the c-myc pathway in prostate cancer cells. Mol. Carcinog. 48:141-149; 2009.

[52] Zhang, L.; Altuwaijri, S.; Deng, F.; Chen, L.; Lal, P.; Bhanot, U. K.; Korets, R.; Wenske, S.; Lilja, H. G.; Chang, C.; Scher, H. I.; Gerald, W. L. NF-אB regulates androgen receptor expression and prostate cancer growth. Am. J. Pathol. 175:489-499; 2009.

[53] Barlow, C. A.; Kitiphongspattana, K.; Siddiqui, N.; Roe, M. W.; Mossman, B. T.; Lounsbury, K. M. Protein kinase A-mediated CREB phosphorylation is an oxidant-induced survival pathway in alveolar type II cells. Apoptosis 13:681-692; 2008.

[54] Ammendola, R.; Mesuraca, M.; Russo, T.; Cimino, F. The DNA-binding efficiency of Sp1 is 
affected by redox changes. Eur. J. Biochem. 225:483-489; 1994.

[55] Faber, P. W.; van Rooij, H. C.; Schipper, H. J.; Brinkmann, A. O.; Trapman, J. Two different, overlapping pathways of transcription initiation are active on the TATA-less human androgen receptor promoter. The role of Sp1. J. Biol. Chem. 268:9296-9301; 1993.

[56] Mizokami, A.; Yeh, S. Y.; Chang, C. Identification of 3',5'-cyclic adenosine monophosphate response element and other cis-acting elements in the human androgen receptor gene promoter. Mol. Endocrinol. 8:77-88; 1994.

[57] Yuan, H.; Gong, A.; Young, C. Y. Involvement of transcription factor Sp1 in quercetin-mediated inhibitory effect on the androgen receptor in human prostate cancer cells. Carcinogenesis 26:793-801; 2005.

[58] Yang, L.; Xie, S.; Jamaluddin, M. S.; Altuwaijri, S.; Ni, J.; Kim, E.; Chen, Y. T.; Hu, Y. C.; Wang, L.; Chuang, K. H.; Wu, C. T.; Chang, C. Induction of androgen receptor expression by phosphatidylinositol 3-kinase/Akt downstream substrate, FOXO3a, and their roles in apoptosis of LNCaP prostate cancer cells. J. Biol. Chem. 280:33558-33565; 2005.

[59] Brooke, G. N.; Bevan, C. L. The role of androgen receptor mutations in prostate cancer progression. Curr. Genomics 10:18-25; 2009.

[60] Culig, Z.; Klocker, H.; Bartsch, G.; Hobisch, A. Androgen receptor mutations in carcinoma of the prostate: significance for endocrine therapy. Am. J. Pharmacogenomics 1:241-249; 2001. 
[61] Brooke, G. N.; Parker, M. G.; Bevan, C. L. Mechanisms of androgen receptor activation in advanced prostate cancer: differential co-activator recruitment and gene expression. Oncogene 27:2941-2950; 2008.

[62] Shiota, M.; Yokomizo, A.; Fujimoto, N.; Naito, S. Androgen receptor cofactors in prostate cancer: potential therapeutic targets of castration-resistant prostate cancer. Curr. Cancer Drug Targets In press; 2011.

[63] Heemers, H. V.; Tindall, D. J. Androgen receptor (AR) coregulators: a diversity of functions converging on and regulating the AR transcriptional complex. Endocr. Rev. 28:778-808; 2007.

[64] Park, S. Y.; Yu, X.; Ip, C.; Mohler, J. L.; Bogner, P. N.; Park, Y. M. Peroxiredoxin 1 interacts with androgen receptor and enhances its transactivation. Cancer Res. 67:9294-9303; 2007.

[65] Chhipa, R. R.; Lee, K. S.; Onate, S.; Wu, Y.; Ip, C. Prx1 enhances androgen receptor function in prostate cancer cells by increasing receptor affinity to dihydrotestosterone. Mol. Cancer Res. 7:1543-1552; 2009.

[66] Hall, A.; Karplus, P. A.; Poole, L. B. Typical 2-Cys peroxiredoxins - structures, mechanisms and functions. FEBS J. 276:2469-2477; 2009.

[67] Kim, Y. J.; Ahn, J. Y.; Liang, P.; Ip, C.; Zhang, Y.; Park, Y. M. Human prx1 gene is a target of $\mathrm{Nrf2}$ and is up-regulated by hypoxia/reoxygenation: implication to tumor biology. Cancer Res. 
67:546-554; 2007.

[68] Shiota, M.; Izumi, H.; Miyamoto, N.; Onitsuka, T.; Kashiwagi, E.; Kidani, A.; Hirano, G.; Takahashi, M.; Ono, M.; Kuwano, M.; Naito, S.; Sasaguri, Y.; Kohno, K. Ets regulates peroxiredoxin1 and 5 expressions through their interaction with the high-mobility group protein B1. Cancer Sci. 99:1950-1959; 2008.

[69] Miyamoto, N.; Izumi, H.; Miyamoto, R.; Kubota, T.; Tawara, A.; Sasaguri, Y.; Kohno, K. Nipradilol and timolol induce Foxo3a and peroxiredoxin 2 expression and protect trabecular meshwork cells from oxidative stress. Invest. Ophthalmol. Vis. Sci. 50:2777-2784; 2009.

[70] Huang, H.; Tindall, D. J. Dynamic FoxO transcription factors. J. Cell. Sci. 120:2479-2487; 2007.

[71] Shiota, M.; Yokomizo, A.; Kashiwagi, E.; Takeuchi, A.; Fujimoto, N.; Uchiumi, T.; Naito, S. Peroxiredoxin 2 in nucleus and cytoplasm distinctly regulates androgen receptor signaling in prostate cancer cells. Free Rad. Biol. Med. 51:78-87; 2011.

[72] Liao, M.; Zhou, Z.; Wilson, E. M. Redox-dependent DNA binding of the purified androgen receptor: evidence for disulfide-linked androgen receptor dimers. Biochemistry 38:9718-9727; 1999.

[73] Zoubeidi, A.; Zardan, A.; Beraldi, E.; Fazli, L.; Sowery, R.; Rennie, P.; Nelson, C.; Gleave, M. Cooperative interactions between androgen receptor (AR) and heat-shock protein 27 facilitate 
AR transcriptional activity. Cancer Res. 67:10455-10465; 2007.

[74] Chen, T.; Wang, L. H.; Farrar, W. L. Interleukin 6 activates androgen receptor-mediated gene expression through a signal transducer and activator of transcription 3-dependent pathway in LNCaP prostate cancer cells. Cancer Res. 60:2132-2135; 2000.

[75] Matsuda, T.; Junicho, A.; Yamamoto, T.; Kishi, H.; Korkmaz, K.; Saatcioglu, F.; Fuse, H.; Muraguchi, A. Cross-talk between signal transducer and activator of transcription 3 and androgen receptor signaling in prostate carcinoma cells. Biochem. Biophys. Res. Commun. 283:179-187; 2001.

[76] Yamamoto, T.; Sato, N.; Sekine, Y.; Yumioka, T.; Imoto, S.; Junicho, A.; Fuse, H.; Matsuda, T. Molecular interactions between STAT3 and protein inhibitor of activated STAT3, and androgen receptor. Biochem. Biophys. Res. Commun. 306:610-615; 2003.

[77] Yang, S. Z.; Abdulkadir, S. A. Early growth response gene 1 modulates androgen receptor signaling in prostate carcinoma cells. J. Biol. Chem. 278:39906-39911; 2003.

[78] Aicher, W. K.; Sakamoto, K. M.; Hack, A.; Eibel, H. Analysis of functional elements in the human Egr-1 gene promoter. Rheumatol. Int. 18:207-214; 1999.

[79] Cunha, G. R.; Donjacour, A. A. Mesenchymal-epithelial interactions in the growth and development of the prostate. Cancer Treat. Res. 46:159-175; 1989.

[80] Byrne, R. L.; Leung, H.; Neal, D. E. Peptide growth factors in the prostate as mediators of 
stromal epithelial interaction. Br. J. Urol. 77:627-633; 1996.

[81] Culig, Z. Androgen receptor cross-talk with cell signalling pathways. Growth Factors 22:179-184; 2004.

[82] Inoue, T.; Yoshida, T.; Shimizu, Y.; Kobayashi, T.; Yamasaki, T.; Toda, Y.; Segawa, T.; Kamoto, T.; Nakamura, E.; Ogawa, O. Requirement of androgen-dependent activation of protein kinase C $\zeta$ for androgen-dependent cell proliferation in LNCaP Cells and its roles in transition to androgen-independent cells. Mol. Endocrinol. 20:3053-3069; 2006.

[83] Kim, J.; Jia, L.; Stallcup, M. R.; Coetzee, G. A. The role of protein kinase A pathway and cAMP responsive element-binding protein in androgen receptor-mediated transcription at the prostate-specific antigen locus. J. Mol. Endocrinol. 34:107-118; 2005.

[84] Ueda, T.; Bruchovsky, N.; Sadar, M. D. Activation of the androgen receptor N-terminal domain by interleukin-6 via MAPK and STAT3 signal transduction pathways. J. Biol. Chem. 277:7076-7085; 2002.

[85] Wang, G.; Jones, S. J.; Marra, M. A.; Sadar, M. D. Identification of genes targeted by the androgen and PKA signaling pathways in prostate cancer cells. Oncogene 25:7311-7323; 2006.

[86] Wang, Y.; Kreisberg, J. I.; Ghosh, P. M. Cross-talk between the androgen receptor and the phosphatidylinositol 3-kinase/Akt pathway in prostate cancer. Curr. Cancer Drug Targets 
7:591-604; 2007.

[87] Müller, J. M.; Cahill, M. A.; Rupec, R. A.; Baeuerle, P. A.; Nordheim, A. Antioxidants as well as oxidants activate c-fos via Ras-dependent activation of extracellular-signal-regulated kinase 2 and Elk-1. Eur. J. Biochem. 244:45-52; 1997.

[88] McCubrey, J. A.; Lahair, M. M.; Franklin, R. A. Reactive oxygen species-induced activation of the MAP kinase signaling pathways. Antioxid. Redox Signal. 8:1775-1789; 2006.

[89] Lo, Y. Y.; Wong, J. M.; Cruz, T. F. Reactive oxygen species mediate cytokine activation of c-Jun NH2-terminal kinases. J. Biol. Chem. 271:15703-15707; 1996.

[90] Torres, M.; Forman, H. J. Redox signaling and the MAP kinase pathways. Biofactors 17:287-296; 2003 .

[91] Xia, Z.; Dickens, M.; Raingeaud, J.; Davis, R. J.; Greenberg, M. E. Opposing effects of ERK and JNK-p38 MAP kinases on apoptosis. Science 270:1326-1331; 1995.

[92] Simon, A. R.; Rai, U.; Fanburg, B. L.; Cochran, B. H. Activation of the JAK-STAT pathway by reactive oxygen species. Am. J. Physiol. 275:C1640-1652; 1998.

[93] Barnett, M. E.; Madgwick, D. K.; Takemoto, D. J. Protein kinase C as a stress sensor. Cell. Signal. 19:1820-1829; 2007.

[94] Clerkin, J. S.; Naughton, R.; Quiney, C.; Cotter, T. G. Mechanisms of ROS modulated cell survival during carcinogenesis. Cancer Lett. 266:30-36; 2008. 
[95] Geller, J.; Albert, J.; Loza, D.; Geller, S.; Stoeltzing, W.; de la Vega, D. DHT concentrations in human prostate cancer tissue. J. Clin. Endocrinol. Metab. 46:440-444; 1978.

[96] Titus, M. A.; Schell, M. J.; Lih, F. B.; Tomer, K. B.; Mohler, J. L. Testosterone and dihydrotestosterone tissue levels in recurrent prostate cancer. Clin. Cancer Res. 11:4653-4657; 2005.

[97] Montgomery, R. B.; Mostaghel, E. A.; Vessella, R.; Hess, D. L.; Kalhorn, T. F.; Higano, C. S.; True, L. D.; Nelson, P. S. Maintenance of intratumoral androgens in metastatic prostate cancer: a mechanism for castration-resistant tumor growth. Cancer Res. 68:4447-4454; 2008.

[98] Locke, J. A.; Guns, E. S.; Lubik, A. A.; Adomat, H. H.; Hendy, S. C.; Wood, C. A.; Ettinger, S. L.; Gleave, M. E.; Nelson, C. C. Androgen levels increase by intratumoral de novo steroidogenesis during progression of castration-resistant prostate cancer. Cancer Res. 68:6407-6415; 2008.

[99] Stanbrough, M.; Bubley, G. J.; Ross, K.; Golub, T. R.; Rubin, M. A.; Penning, T. M.; Febbo, P. G.; Balk, S. P. Increased expression of genes converting adrenal androgens to testosterone in androgen-independent prostate cancer. Cancer Res. 66:2815-2825; 2006.

[100] Mohler, J. L.; Gregory, C. W.; Ford, O. H. 3rd.; Kim, D.; Weaver, C. M.; Petrusz, P.; Wilson, E. M.; French, F. S. The androgen axis in recurrent prostate cancer. Clin. Cancer Res. 10:440-448; 2004. 
[101] Fung, K. M.; Samara, E. N.; Wong. C.; Metwalli, A.; Krlin, R.; Bane, B.; Liu, C. Z.; Yang, J. T.; Pitha, J. V.; Culkin, D. J.; Kropp, B. P.; Penning, T. M.; Lin, H. K. Increased expression of type $23 \alpha$-hydroxysteroid dehydrogenase/type 5 17ß-hydroxysteroid dehydrogenase (AKR1C3) and its relationship with androgen receptor in prostate carcinoma. Endocr. Relat. Cancer 13:169-180; 2006.

[102] Xu, Y.; Dalrymple, S. L.; Becker, R. E.; Denmeade, S. R.; Isaacs, J. T. Pharmacologic basis for the enhanced efficacy of dutasteride against prostatic cancers. Clin. Cancer Res. 12:4072-4079; 2006.

[103] Gregory, C. W.; Johnson, R. T. Jr.; Mohler, J. L.; French, F. S.; Wilson, E. M. Androgen receptor stabilization in recurrent prostate cancer is associated with hypersensitivity to low androgen. Cancer Res. 61:2892-2898; 2001.

[104] Sharifi, N.; Hurt, E. M.; Thomas, S. B.; Farrar, W. L. Effects of manganese superoxide dismutase silencing on androgen receptor function and gene regulation: implications for castration-resistant prostate cancer. Clin. Cancer Res. 14:6073-6080; 2008.

[105] Isbarn, H.; Boccon-Gibod, L.; Carroll, P. R.; Montorsi, F.; Schulman, C.; Smith, M. R.; Sternberg, C. N.; Studer, U. E. Androgen deprivation therapy for the treatment of prostate cancer: consider both benefits and risks. Eur. Urol. 55:62-75; 2009.

[106] Nelson, C. J.; Lee, J. S.; Gamboa, M. C.; Roth, A. J. Cognitive effects of hormone therapy in 
men with prostate cancer: a review. Cancer 113:1097-1106; 2008.

[107] Taylor, L. G.; Canfield, S. E.; Du, X. L. Review of major adverse effects of androgen-deprivation therapy in men with prostate cancer. Cancer 115:2388-2399; 2009.

[108] Siris, E. S.; Miller, P. D.; Barrett-Connor, E.; Faulkner, K. G.; Wehren, L. E.; Abbott, T. A.; Berger, M. L.; Santora, A. C.; Sherwood, L. M. Identification and fracture outcomes of undiagnosed low bone mineral density in postmenopausal women: results from the National Osteoporosis Risk Assessment. JAMA 286:2815-2822; 2001.

[109] Chandler, J. M.; Zimmerman, S. I.; Girman, C. J.; Martin, A. R.; Hawkes, W.; Hebel, J. R.; Sloane, P. D.; Holder, L.; Magaziner, J. Low bone mineral density and risk of fracture in white female nursing home residents. JAMA 284:972-977; 2000.

[110] Muthusami, S.; Ramachandran, I.; Muthusamy, B.; Vasudevan, G.; Prabhu, V.; Subramaniam, V.; Jagadeesan, A.; Narasimhan, S. Ovariectomy induces oxidative stress and impairs bone antioxidant system in adult rats. Clin. Chim. Acta. 360:81-86; 2005.

[111] Garrett, I. R.; Boyce, B. F.; Oreffo, R. O.; Bonewald, L.; Poser, J.; Mundy, G. R. Oxygen-derived free radicals stimulate osteoclastic bone resorption in rodent bone in vitro and in vivo. J. Clin. Invest. 85:632-639; 1990.

[112] Yang, S.; Madyastha, P.; Bingel, S.; Ries, W.; Key, L. A new superoxide-generating oxidase in murine osteoclasts. J. Biol. Chem. 276:5452-5458; 2001. 
[113] Lean, J. M.; Jagger, C. J.; Kirstein, B.; Fuller, K.; Chambers, T. J. Hydrogen peroxide is essential for estrogen-deficiency bone loss and osteoclast formation. Endocrinology 146:728-735; 2005.

[114] Deyhim, F.; Villarreal, A.; Garcia, K.; Rios, R.; Garcia, C.; Gonzales, C.; Mandadi, K.; Patil, B. S. Orange pulp improves antioxidant status and suppresses lipid peroxidation in orchidectomized male rats. Nutrition 23:617-621; 2007.

[115] Deyhim, F.; Mandadi, K.; Patil, B. S.; Faraji, B. Grapefruit pulp increases antioxidant status and improves bone quality in orchidectomized rats. Nutrition 24:1039-1044; 2008.

[116] Mandadi, K.; Ramirez, M.; Jayaprakasha, G. K.; Faraji, B.; Lihono, M.; Deyhim, F.; Patil, B. S. Citrus bioactive compounds improve bone quality and plasma antioxidant activity in orchidectomized rats. Phytomedicine 16:513-520; 2009.

[117] Tomkinson, A.; Reeve, J.; Shaw, R. W.; Noble, B. S. The death of osteocytes via apoptosis accompanies estrogen withdrawal in human bone. J. Clin. Endocrinol. Metab. 82:3128-3135; 1997.

[118] Tomkinson, A.; Gevers, E. F.; Wit, J. M.; Reeve, J.; Noble, B. S. The role of estrogen in the control of rat osteocyte apoptosis. J. Bone Miner. Res. 13:1243-1250; 1998.

[119] Kousteni, S.; Bellido, T.; Plotkin, L. I.; O'Brien, C. A.; Bodenner, D. L.; Han, L.; Han, K.; DiGregorio, G. B.; Katzenellenbogen, J. A.; Katzenellenbogen, B. S.; Roberson, P. K.; 
Weinstein, R. S.; Jilka, R. L.; Manolagas. S. C. Nongenotropic, sex-nonspecific signaling through the estrogen or androgen receptors: dissociation from transcriptional activity. Cell 104:719-730; 2001.

[120] O'Brien, C. A.; Jia, D.; Plotkin, L. I.; Bellido, T.; Powers, C. C.; Stewart, S. A.; Manolagas, S. C.; Weinstein, R. S. Glucocorticoids act directly on osteoblasts and osteocytes to induce their apoptosis and reduce bone formation and strength. Endocrinology 145:1835-1841; 2004.

[121] Ahlbom, E.; Prins, G. S.; Ceccatelli, S. Testosterone protects cerebellar granule cells from oxidative stress-induced cell death through a receptor mediated mechanism. Brain Res. 892:255-262; 2001.

[122] Hammond, J.; Le, Q.; Goodyer, C.; Gelfand, M.; Trifiro, M.; LeBlanc, A. Testosterone-mediated neuroprotection through the androgen receptor in human primary neurons. J. Neurochem. 77:1319-1326; 2001.

[123] Ramsden, M.; Shin, T. M.; Pike, C. J. Androgens modulate neuronal vulnerability to kainate lesion. Neuroscience 122:573-578; 2003.

[124] Lewis, C.; McEwen, B. S.; Frankfurt, M. Estrogen-induction of dendritic spines in ventromedial hypothalamus and hippocampus: effects of neonatal aromatase blockade and adult GDX. Brain Res. Dev. Brain Res. 87:91-95; 1995.

[125] Garcia-Segura, L. M.; Luquín, S.; Párducz, A.; Naftolin, F. Gonadal hormone regulation of 
glial fibrillary acidic protein immunoreactivity and glial ultrastructure in the rat neuroendocrine hypothalamus. Glia 10:59-69; 1994.

[126] Markianos, M.; Panas, M.; Kalfakis, N.; Vassilopoulos, D. Plasma testosterone in male patients with Huntington's disease: relations to severity of illness and dementia. Ann. Neurol.

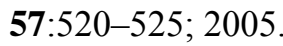

[127] Militello, A.; Vitello, G.; Lunetta, C.; Toscano, A.; Maiorana, G.; Piccoli, T.; La Bella, V. The serum level of free testosterone is reduced in amyotrophic lateral sclerosis. J. Neurol. Sci. 195:67-70; 2002.

[128] Okun, M. S.; Walter, B. L.; McDonald, W. M.; Tenover, J. L.; Green, J.; Juncos, J. L.; DeLong, M. R. Beneficial effects of testosterone replacement for the nonmotor symptoms of Parkinson disease. Arch. Neurol. 59:1750-1753; 2002.

[129] Okun, M. S.; DeLong, M. R.; Hanfelt, J.; Gearing, M.; Levey, A. Plasma testosterone levels in Alzheimer and Parkinson diseases. Neurology 62:411-413; 2004.

[130] Rubinow, D. R.; Schmidt, P. J. Androgens, brain, and behavior. Am. J. Psychiatry 153:974-984; 1996.

[131] Anderson, K. E.; Marder, K. S. An overview of psychiatric symptoms in Huntington's disease. Curr. Psychiatry Rep. 3:379-388; 2001.

[132] Bonelli, R. M.; Hofmann, P. A review of the treatment options for Huntington's disease. Expert. 
Opin. Pharmacother. 5:767-776; 2004.

[133] La Fontaine, M. A.; Geddes, J. W.; Banks, A.; Butterfield, D. A. 3-nitropropionic acid induced in vivo protein oxidation in striatal and cortical synaptosomes: insights into Huntington's disease. Brain Res. 858:356-362; 2000.

[134] Túnez, I.; Collado, J. A.; Medina, F. J.; Peña, J.; Del C Muñoz, M.; Jimena, I.; Franco, F.; Rueda, I.; Feijóo, M.; Muntané, J.; Montilla, P. 17ß-Estradiol may affect vulnerability of striatum in a 3-nitropropionic acid-induced experimental model of Huntington's disease in ovariectomized rats. Neurochem. Int. 48:367-373; 2006.

[135] Túnez, I.; Feijóo, M.; Collado, J. A.; Medina, F. J.; Peña, J.; Muñoz Mdel, C.; Jimena, I.; Franco, F.; Rueda, I.; Muntané, J.; Montilla, P. Effect of testosterone on oxidative stress and cell damage induced by 3-nitropropionic acid in striatum of ovariectomized rats. Life Sci. 80:1221-1227; 2007.

[136] Nowak, J.; Murray, J. J.; Oates, J. A.; FitzGerald, G. A. Biochemical evidence of a chronic abnormality in platelet and vascular function in healthy individuals who smoke cigarettes. Circulation 76:6-14; 1987.

[137] Davì, G.; Averna, M.; Catalano, I.; Barbagallo, C.; Ganci, A.; Notarbartolo, A.; Ciabattoni, G.; Patrono, C. Increased thromboxane biosynthesis in type IIa hypercholesterolemia. Circulation 85:1792-1798; 1992. 
[138] Davì, G.; Catalano, I.; Averna, M.; Notarbartolo, A.; Strano, A.; Ciabattoni, G.; Patrono, C. Thromboxane biosynthesis and platelet function in type II diabetes mellitus. N. Engl. J. Med. 322:1769-1774; 1990.

[139] Patrono, C. Aspirin as an antiplatelet drug. N. Engl. J. Med. 330:1287-1294; 1994.

[140] Ridker, P. M. High-sensitivity C-reactive protein: potential adjunct for global risk assessment in the primary prevention of cardiovascular disease. Circulation 103:1813-1818; 2001.

[141] Maytin, M.; Leopold, J.; Loscalzo, J. Oxidant stress in the vasculature. Curr. Atheroscler. Rep. 1:156-164; 1999.

[142] Shahidi, N. T. A review of the chemistry, biological action, and clinical applications of anabolic-androgenic steroids. Clin. Ther. 23:1355-1390; 2001.

[143] Li, S.; Li, X.; Li, J.; Deng, X.; Li, Y.; Cong, Y. Experimental arterial thrombosis regulated by androgen and its receptor via modulation of platelet activation. Thromb. Res. 121:127-134; 2007.

[144] Li, S.; Li, X.; Li, J.; Deng, X.; Li, Y. Inhibition of oxidative-stress-induced platelet aggregation by androgen at physiological levels via its receptor is associated with the reduction of thromboxane A2 release from platelets. Steroids 72:875-880; 2007.

[145] Dhalla, N. S.; Temsah, R. M.; Netticadan, T. Role of oxidative stress in cardiovascular diseases. J. Hypertens. 18:655-673; 2000. 
[146] Molavi, B.; Mehta, J. L. Oxidative stress in cardiovascular disease: molecular basis of its deleterious effects, its detection, and therapeutic considerations. Curr. Opin. Cardiol. 19:488-493; 2004.

[147] Cave, A.; Grieve, D.; Johar, S.; Zhang, M.; Shah, A. M. NADPH oxidase-derived reactive oxygen species in cardiac pathophysiology. Philos. Trans. R. Soc. Lond. B. Biol. Sci. 360:2327-2334; 2005.

[148] Schaible, T. F.; Malhotra, A.; Ciambrone, G.; Scheuer, J. The effects of gonadectomy on left ventricular function and cardiac contractile proteins in male and female rats. Circ. Res. 54:38-49; 1984.

[149] Kłapcińska, B.; Jagsz, S.; Sadowska-Krepa, E.; Górski, J.; Kempa, K.; Langfort, J. Effects of castration and testosterone replacement on the antioxidant defense system in rat left ventricle. J. Physiol. Sci. 58:173-177; 2008.

[150] Hakimian, P.; Blute, M. Jr.; Kashanian, J.; Chan, S.; Silver, D.; Shabsigh, R. Metabolic and cardiovascular effects of androgen deprivation therapy. BJU Int. 102:1509-1514; 2008.

[151] Irani, K.; Xia, Y.; Zweier, J. L.; Sollott, S. J.; Der, C. J.; Fearon, E. R.; Sundaresan, M.; Finkel, T.; Goldschmidt-Clermont, P. J. Mitogenic signaling mediated by oxidants in Ras-transformed fibroblasts. Science 275:1649-1652; 1997.

[152] Seril, D. N.; Liao, J.; Ho, K. L.; Yang, C. S.; Yang, G. Inhibition of chronic ulcerative 
colitis-associated colorectal adenocarcinoma development in a murine model by $N$-acetylcysteine. Carcinogenesis 23:993-1001; 2002.

[153] Havre, P. A.; O'Reilly, S.; McCormick, J. J.; Brash, D. E. Transformed and tumor-derived human cells exhibit preferential sensitivity to the thiol antioxidants, $N$-acetyl cysteine and penicillamine. Cancer Res. 62:1443-1449; 2002.

[154] Agarwal, A.; Muñoz-Nájar, U.; Klueh, U.; Shih, S. C.; Claffey, K. P. N-acetyl-cysteine promotes angiostatin production and vascular collapse in an orthotopic model of breast cancer. Am. J. Pathol. 164:1683-1696; 2004.

[155] Baas, P.; Oppelaar, H.; van der Valk, M. A.; van Zandwijk, N.; Stewart, F. A. Partial protection of photodynamic-induced skin reactions in mice by $\mathrm{N}$-acetylcysteine: a preclinical study. Photochem. Photobiol. 59:448-454; 1994.

[156] Emonet-Piccardi, N.; Richard, M. J.; Ravanat, J. L.; Signorini, N.; Cadet, J.; Béani, J. C. Protective effects of antioxidants against UVA-induced DNA damage in human skin fibroblasts in culture. Free Radic. Res. 29:307-313; 1998.

[157] Albini, A.; Morini, M.; D'Agostini, F.; Ferrari, N.; Campelli, F.; Arena, G.; Noonan, D. M.; Pesce, C.; De Flora, S. Inhibition of angiogenesis-driven Kaposi's sarcoma tumor growth in nude mice by oral $N$-acetylcysteine. Cancer Res. 61:8171-8178; 2001.

[158] De Flora, S.; D'Agostini, F.; Masiello, L.; Giunciuglio, D.; Albini, A. Synergism between 
$N$-acetylcysteine and doxorubicin in the prevention of tumorigenicity and metastasis in murine models. Int. J. Cancer 67:842-848; 1996.

[159] De Flora, S.; Izzotti, A.; D'Agostini, F.; Balansky, R. M. Mechanisms of $N$-acetylcysteine in the prevention of DNA damage and cancer, with special reference to smoking-related end-points. Carcinogenesis 22:999-1013; 2001.

[160] Tam, N. N.; Nyska, A.; Maronpot, R. R.; Kissling, G.; Lomnitski, L.; Suttie, A.; Bakshi, S.; Bergman, M.; Grossman, S.; Ho, S. M. Differential attenuation of oxidative/nitrosative injuries in early prostatic neoplastic lesions in TRAMP mice by dietary antioxidants. Prostate 66:57-69; 2006.

[161] van Zandwijk, N.; Dalesio, O.; Pastorino, U.; de Vries, N.; van Tinteren, H. EUROSCAN, a randomized trial of vitamin A and $\mathrm{N}$-acetylcysteine in patients with head and neck cancer or lung cancer. For the EUropean Organization for Research and Treatment of Cancer Head and Neck and Lung Cancer Cooperative Groups. J. Natl. Cancer Inst. 92:977-986; 2000.

[162] Ansari, M. S.; Gupta, N. P. A comparison of lycopene and orchidectomy vs orchidectomy alone in the management of advanced prostate cancer. BJU Int. 92:375-378; 2003.

[163] Matlaga, B. R.; Hall, M. C.; Stindt, D.; Torti, F. M. Response of hormone refractory prostate cancer to lycopene. J. Urol. 166:613; 2001.

[164] Watters, J. L.; Gail, M. H.; Weinstein, S. J.; Virtamo, J.; Albanes, D. Associations between 
$\alpha$-tocopherol, $\beta$-carotene, and retinol and prostate cancer survival. Cancer Res. 69:3833-3841; 2009.

[165] Chaiswing, L.; Bourdeau-Heller, J. M.; Zhong, W.; Oberley, T. D. Characterization of redox state of two human prostate carcinoma cell lines with different degrees of aggressiveness. Free Radic. Biol. Med. 43:202-215; 2007.

[166] Chaiswing, L.; Zhong, W.; Cullen, J. J.; Oberley, L. W.; Oberley, T. D. Extracellular redox state regulates features associated with prostate cancer cell invasion. Cancer Res. 68:5820-5826; 2008. 


\section{Figure Legends}

Fig. 1. Schematic representation of the links among androgen-deprivation therapy, oxidative stress, androgen receptor signaling, and castration-resistant prostate cancer.

Fig. 2. Schematic representation of the signaling pathways on androgen receptor signaling in prostate cancer by oxidative stress. Oxidative stress activates the signaling pathways circled (transcription factors, AR co-regulators and intracellular signal-transduction pathways), resulting in an activation of AR signaling pathway. 


\section{Figure 1 Shiota et al.}

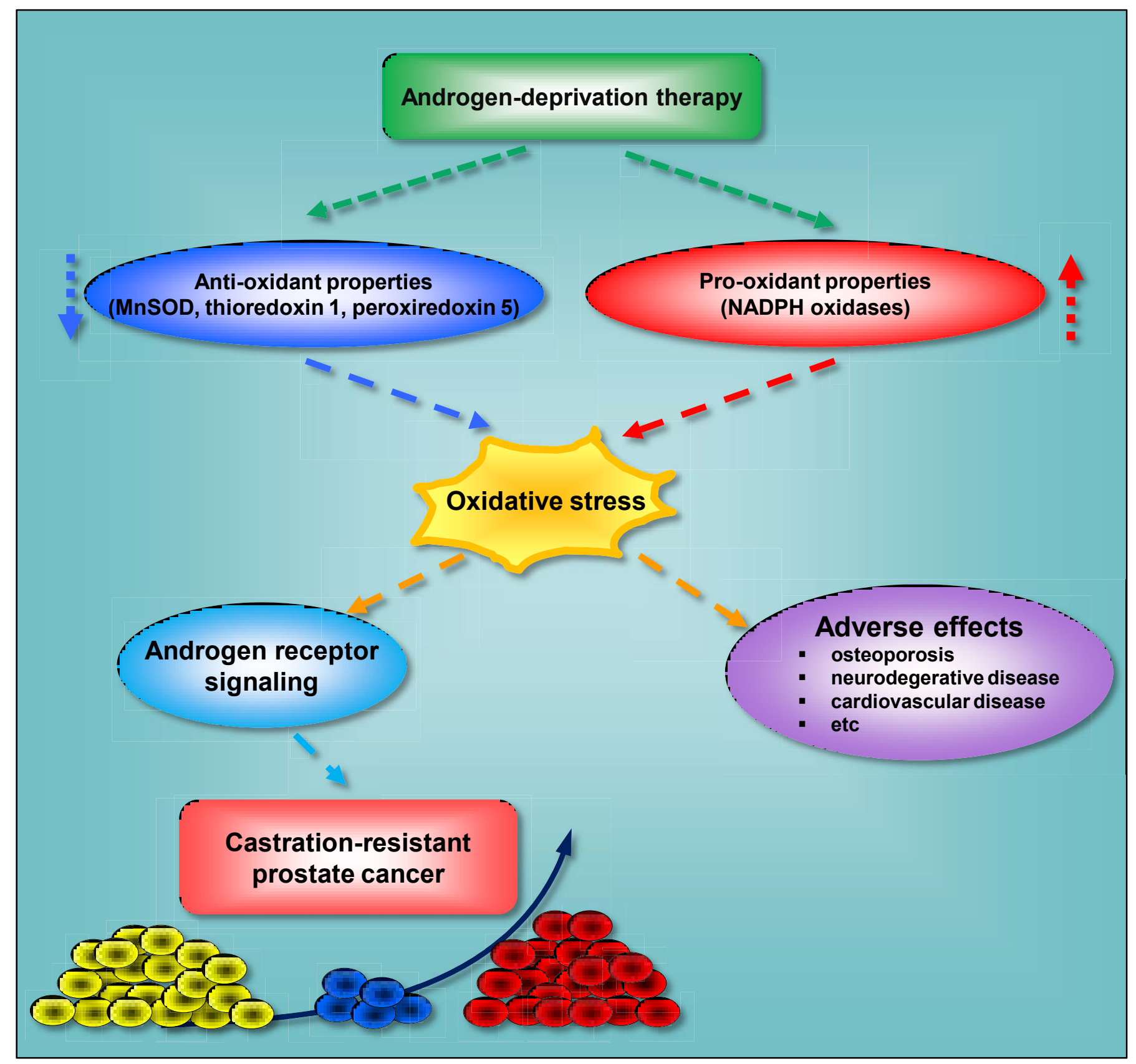




\section{Figure 2 Shiota et al.}



